\title{
Tourism and Poverty in Badung Regency, Bali
}

\section{Made Patera, I Made Sukarsa and Agung Suryawan Wiranatha}

\author{
School of Postgraduate Study \\ Doctorate Degree in Tourism Udayana University
}

Coressponding author: made_patera@purimesari.com

\section{ARTICLE INFO \\ Received \\ 11 March 2015 \\ Accepted \\ 19 August 2015 \\ Available online \\ 07 September 2015}

\begin{abstract}
Tourism and poverty's phenomenon had already been known since the birth of human civilization. In the 1980s poverty became a serious concern of practitioners and scholars in various part of the world, including Indonesia. Poverty is not only understood in understanding as an abstract concept, but also as a reality of economic injustice and inability to meet basic human needs in some rich countries but also in many developing countries in the world. The problem of poverty is a fundamental and tourism is one of the many ways to solve this. The objective of this paper is to study the role of tourism to poverty alleviation including: 1) to analyze the influence of tourism development toward economic performance; 2 ) to analyze the effect of economic performance on poverty eradication; 3 ) to analyze the influence of tourism on poverty alleviation; 4) to formulate a strategy to increase tourism's role in poverty alleviation in Badung Regency. This study uses quantitative approach supported by secondary data and qualitative approach using primary data obtained through observation, in-depth interviews and focus group discussions. Research was conducted in South Badung Regency in the most developed tourism growth and considered the richest district among all regencies in Bali Regencies. Various attempts have been made to alleviate poverty, however have not been able to resolve poverty problems. The grand theory of this study refers to Neoliberalism Theory, supported by Social Democratic Theory and Empowerment Theory. Neoliberalism emphasizes that poverty as an individual problem and prosperity can only be achieved by achievement of economic growth through free market mechanism. According to Social Democratic Theory the emergence of poverty came from outside of the community itself. While the emphasis on the Empowerment Theory is in improving the ability of individual or communities to become indepedence on economic, social welfare and political right. Data analysis using Partial Least Square (PLS) with statistical analysis descriptive and inferential statistics. In order to have a better understanding on the statiscal result, Descriptive Analysis is also used to describe the researched data, using inferential statistical analysis to test the research hypothesis. The results of the research indicated that: 1) the development of tourism showed positive and significant impact on economic performance; 2) economic performance showed negative and significant impact on poverty alleviation; 3) tourism development showed negative and significant effect on poverty alleviation and (4) in order to be able to increase tourism's role in poverty alleviation in Badung Regency the strategy is formulated by analyzing the strengths, weakness, opportunities and challenges based on Strength, Weakness, Opportunity and Threat (SWOT) strategy.
\end{abstract}

Keywords: tourism development, economic performance, poverty 


\section{Introduction}

\section{Background}

The development of international tourism has a positive impact on the growth of the global economy (UNWTO, 2015). According to Bryden (1973) tourism is a growing source of revenue for development in developing countries. The government through the Master Plan for the Acceleration and Expansion of Indonesian Economic Development (MP3EI) 2011-2025 designs Competitive Program to increase tourist arrivals from the addition of direct flights to Indonesia, the development of Meeting, Incentive, Convention, and Exhibition (MICE), to the development of Raja Ampat, Indonesia's tourism has its impact on increasing tourist arrivals to Bali. Bali Tourism Office (2014: 58) states that the average spending of domestic tourists in Bali a year from 2009 to 2013 amounted to 548,000 rupiahs per day with an average length of stay for 4 (four) days, while the average spending of foreign tourists amount to USD 158.60 including the cost of accommodation, eating and drinking and other travel expenses, excluding the cost of the flight. The average length of stay of foreign tourists in Bali is for 9.24 days.

Badung district has a strategic position, with the presence of the international airport Ngurah Rai as the main gateway for the entry of foreign and domestic tourists. Investment growth in tourism strengthens Badung regency as the largest producer of Gross Domestic Product (GDP) at 23.6 trillion in 2014 increased from Rp. 20.9 trillion in 2013. Supported by the rapid growth of tourism in the district of South Kuta, the village of Jimbaran and Pecatu village, and the magnitude of the potential of eco-tourism in the district of Petangat Plaga Village and Belok Sidan Village as agriculture and ecotourism area make Badung more potential as the center of tourism growth. The rapid growth of tourism in Badung district makes Badung the richest district in Bali which raises a big question as to why there is still poverty in Badung Regency. This research was based on the research by Ashley and Roe (2001) which states that tourism growth has a positive impact on alleviating poverty and the research stating the reverse by Jamieson et al. (2004: 2) and Roy (2010: 4) which states that tourism is not able to alleviate poverty.

\section{Research Objectives}

This study aims to:

1) Analyze the influence of tourism on the economy's performance in Badung Regency.

2) Analyze the effect of economic performance on poverty in Badung Regency.

3) Analyze the influence of tourism development on poverty in Badung Regency.

4) Formulate a strategy to increase tourism's role in poverty alleviation in Badung Regency.

\section{Literature Review}

\section{Previous Research}

Research conducted in poor populated areas in Bangladesh by Anwar (2012) states that tourism growth positively affects the economy of poor community, and is able to increase the income and welfare of the community.

Wood (2005) who examines the "propoor tourism in Uctubamba Valley, Northern Peru" states that local tourism planning has an impact on poverty reduction. Spenceley and Seif (2003) who analyze the pro poor tourism of private companies in the field of tourism in South Africa state that tourism is able to overcome poverty problems for people who live in tourist destinations in South Africa. While Ashley et al. (2001) analyze the strategy pro poor tourism in South Africa, Namibia, Uganda, St Lucia, Ecuador and Nepal about Making Tourism Work for the Poor, states that the pro-poor tourism is very positive towards the opening of employment opportunities, equitable income generation for the community, the growth of micro economy, and the reduction of the number of the poor. While the research by Hidayat and Widjanarko (2012)(Hidayat and Widjanarko, 2012) on "The Development of Community-Based Agrotourism East Java," states that community-based tourism contributes to improving people's welfare. 


\section{Theoretical Framework}

\section{Theory of Empowerment}

Empowerment theory is used to examine the psychological concepts related to personal development, a group of people or community. Rappaport (1987: 139-142) states that the beneficial empowerment to improve the ability of a person in determining the choice of interests that have a positive impact for himself. While Perkins and Zimmerman (1995: 570-571) state that empowerment is a structured process of participation to eliminate various limitations, increase self-confidence, emotional maturity, and tolerance.

\section{Pro-Poor Tourism}

Pro-poor tourism (PPT) is put into a discourse by multilateral institutions and nongovernmental organizations (NGOs) to contribute positively to the economic growth of a country. According to Scheynes and Momsen (2008), tourism is able to improve social welfare and reduce poverty. Ashley and Roe (2001) state that pro-poor tourism provides a positive economic impact for the poor. Furthermore, Roe et al. (2001) state that the pro-poor tourism opens employment opportunities, availability of training to improve the skills to get better jobs and higher incomes. While Anwar (2012: 15) states that the pro-poor tourism gives direct benefits to the poor through education, ongoing training, and provides adequate health and education facilities.

\section{Community-Based Tourism}

\section{Community-Based Tourism (CBT)} contributes to economy of rural communities or those living in small towns with low living standards by involving them in tourism activities, cultural preservation and the environment (Goodwin and Santili, 2009: 4). Tasci, Semrad and Yilmaz (2013) state that the concept of community-based tourism boosts economic growth of poor community who traditionally live as farmers or poor fishermen in the tourist areas. According to Joppe (1996: 475) CBT management involving local informal leaders in the development of local tourism alleviates poverty.

Community-Based Tourism relying on empowerment and independence serve as the basis for developing sustainable tourism. According to Armstrong (2012), the basic concept of community-based tourism is as follows: (1) a participatory approach to the public and is likely to include the ownership society as a partner in development local tourism, (2) involve the community as an active manager and, (3) use the results of tourism to improve the welfare of society in order to eradicate poverty.

\section{Tourism Development Concept}

World tourism development contributesto foreign exchange earnings to development in developing countries which make tourism boost economic growth and improve social welfare. Theobald (2005: 163-165) states that tourism development has a positive impact on the social, cultural and environmental preservation while Schilcher (2007: 58) states the importance of research to determine the potential and problems of tourism development activities and the importance of promotional activities through printed media, electronic media, and multimedia to accelerate the introduction of developed tourist destinations.

\section{Tourism and Economic Performance}

Global tourism plays a role as a driver of economic growth, sustainability of sociocultural preservation, and has the potential to sustain local traditions and enhancing the quality of human life including the fullest and increased availability of food for the community (Wall and Mathieson, 2006: 7778). The increasing role of tourism substantially provides a lot of benefits enjoyed by developing countries such as foreign exchange earnings as a source of development, the occurrence of multiplier effect, i.e. the chain of income from one business unit to another business unit and the impact on tax revenues to alleviate poverty (Richardson, 2010: 1).

According to Athanasopoulou (2013) the tourism chain is service and trade activities between countries to improve economic performance, export import, growth in investment, labor supply and other services 
related to tourism services such as:

1) International tourist arrivals

2) International tourism receipts

3) Expenditure on international travel

4) Trade in travel services

5) Travel and tourism industry's contribution to GDP

6) Travel and tourism industry's contribution to employment

7) Travel and tourism industry's contribution to capital investment

\section{The Concept of Poverty}

The concept of poverty according to the National Development Planning Agency (2010: 8-10) is divided into relative poverty, namely the inability to meet basic needs as a result of the influence of development policies that have an impact on people's income inequality and absolute poverty is the poverty of the inability to meet the most basic necessities of life such as food and clothing, health, education, as well as the need for clean water. According to Elesh (1973), the concept of cultural poverty occurs as a result of the internal behavior of individuals and groups of people that causes them to be unable to do social mobility and external influences such as impartiality of government to the poor. Meanwhile, according to Laderchi et al. (2006), the concept of poverty in the form of an inability to meet basic needs in the economy and the limited participation of political and social culture. The World Bank in the Millennium Development Goals (MDG) determines the poverty standard of $\$ 1.00$ /day in 1999 and US \$ 1.25/day in 2005.

\section{Type of Poverty}

By type, poverty is divided into three types: (1) natural poverty, caused by human beings themselves as the absence of an intention to change from habits of a life in poverty, lack of education and resources owned, (2) cultural poverty, linked to the attitude of a person or group in a community that does not want to improve his own quality of life although there are other parties that want to provide assistance, (3) structural poverty, caused by institutional, governmental organizations or order of the social structure that lead to vertical immobility where the rich continue to enjoy their wealth while poor people still live in poverty (Harniati, 2007; Soedjatmiko, 2007).

\section{Causes of Poverty}

Causes of poverty are a vicious circle which arises from various factors that influence one another directly or indirectly. This is caused by the economic and political system of the world that does not show partiality to the poor. (Corbett and Fikkert, 2012: 11).

Nehen (2012) states the causes of poverty are: (1) low levels of education which are directly correlated with performance and low productivity of labor and consequently with lower income received, (2) limited employment opportunities which correlate with educational facilities and health facilities which have an impact on the worsening condition of the community, (3) culture of the community that resists change for a better life. Meanwhile, according to Papilaya and Nastiti (2013) the causes of poverty include: (1) a person's behavior, i.e. low effort to change attitudes to abandon old habits, (2) personal factors such as lack of knowledge, personality, value systems and attitudes to act, (3) situational factors such as the influence of environmental, social, cultural and economic, and (4) the inability of the government to improve welfare and increase equity and incomes of the community.

Framework of Thinking

Framework of thinking is composed of theoretical abstraction and previous research studies supported by empirical studies of the development of tourism in Badung Regency. An increase in tourist arrivals, Trade, Hotels and Restaurants (PHR), employment absorption, investment in tourism and higher original regional revenue (PAD) supports the highest achievement of Badung Regency in the economic sector. (BPS Badung, 2014). According to the World Bank (2013: 7-9), tourism development opens investments, drives economic growth, opens work opportunities, and increases government revenues through tourism sectors. Research in developing countries proves that if tourism management strategies is directed towardspropoor tourism, tourism can enhance the welfare 
of society (Goodwin, 1996; Scheyvens, 2002; Guo, 2008).

Another strategy is more focused orientation of tourism development by shortening the distribution chain of tourism revenueto optimize its role in poverty alleviation, facilitating local communities with tourists in the provision of tourist needs or in development of more attractive tourist destinations and benefit local communities (Harrison, 2008)(Harrison, 2008). The way to do is to involve local communities to participate in the decision-making process in tourism activities in accordance with the availability and capacity of the local community resources (Ashley and Roe, 2002; Ashley and Haysom, 2006; Selinger, 2009).

Hypotheses

The hypotheses proposed in this study are as follows:

H1: Development of tourism has a significant and positive effect on economic performance.

$\mathrm{H} 2$ : Economic performance has a negative and significant effect on poverty

H3: Tourism development has a negative and significant effect on poverty.

\section{Methodology}

\section{Methods}

This study uses a combination of quantitative and qualitative or Mixed Method. It is based on the view of Creswell (2013) which states that the more complex problem of the study, using qualitative and quantitative methods in the study will reinforce each rather than just using one method of research separately. Quantitative research was conducted through the collection of secondary data from data sources available at Statistics Office, Regional Work Unit Officeof Badung Regency and writings related to the research are available at other institutions. The data were processed by inferential statistical analysis using Partial Least Square (PLS). Results of hypothesis testing were used to confirm the results of research and theories referenced (Jennings, 2001; Denzin and Lincoln, 2008). A qualitative approach was also done because most of the problems under

http://ojs.unud.ac.id/index.php/eot study wereconducted through a descriptive search, through observation, in-depth interviews where the researcher serves as a key instrument to do research directly at the field. To determine the characteristics of poverty, descriptive statistics was used aiming to confirm results of quantitative analysis. Activities of focus group discussions were conducted in the village of BelokSidan and Pelaga in North Badung districts and the village of Jimbaran and Pecatu in the district of South Kuta.

\section{Location, Time, and Research Object}

The study was conducted in different tourist destinations i.e. in North Badung areas, in the district of Petang, the village of Plagaand BelokSidan and in South Badungareas, in the district of South Kuta, namely in the village of Pecatu and Jimbaran. The research was conducted on October 2014 through June 2015. The research location is presented in Figure 1.

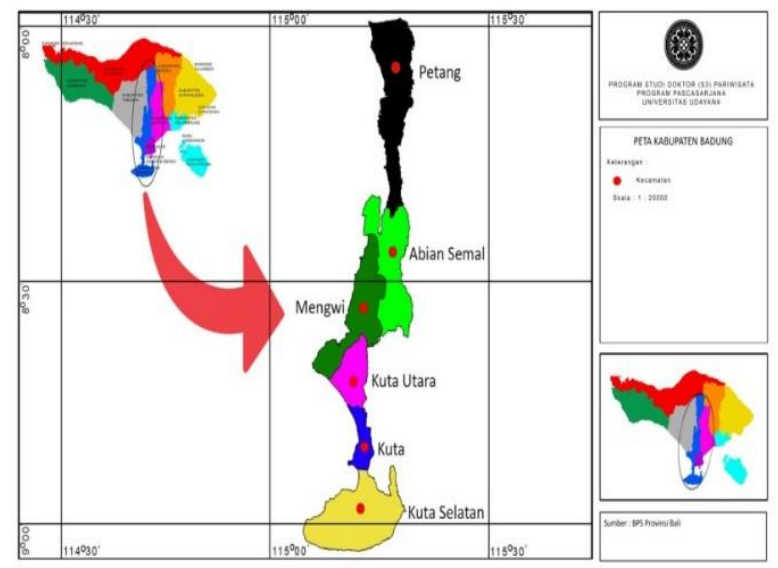

Figure 1. Research Location

\section{Research Variables}

\section{Identification of Variables}

Variables or factorsare something that will be the object of observation in a study. Based on the issues and the research hypothesis, variables of this study can be identified as follows:

1) The independent variables (independent/ exogenous variable), namely Tourism Development (X1), the variables that affect or cause changes in another variable. 
2) The second independent variable (independent/ exogenous variable), namely Economic Performance (X2), the variables that affect poverty variables.

3) The dependent variable (dependent/endogenous variable) i.e. Poverty variable $(\mathrm{Y})$, a variable that is influenced by other variables namely the Tourism Development and Economic Performance.

\section{Population}

Population is a collection of individuals or objects of research that has quality-quantity and characteristics that have been specified. Population is also used to refer to all elements or a member of an area of targeted research (Juliansyah, 2011). The population in this study is the elements of poor people that exist in Badung regency, i.e. North Badung, Petang district, village of Pelaga and Belok Sidan and South, and in South Badung, the district of South Kuta covering Jimbaran village and Pecatu village.

\section{Sample}

Samples are part of the population that has the same characteristics or the one that can be representative of the population. The method of selecting the sample in this study using purposive sampling (Wahyuni, 2012), by first determining the criteria relevant to research related to the development of tourism, economic performance and poverty in Badung regency.

With purposive sampling method, three informants were chosen for in-depth interviews, five informants for other kind of interviews and eight people were chosen for a focus group discussions conducted in the village of Belok Sidan, Jimbaran village and the village of Pecatu.

\section{Types of data}

The type of data used in this study is the quantitative and qualitative data as follows:

1) The quantitative data

The information in the form of numbers has a unit of calculation, the value of which http://ojs.unud.ac.id/index.php/eot can be varying or varied such as: the number of tourist arrivals, length of stay or the amount spending, obtained from the documents available on the BPS office Badung Regency, Bappedaof Badung Regency, BPS of Bali Province, and BPMPD of Bali Province.

\section{2) Qualitative Data}

The type of data that is not in the form of numbers does not have a unit of calculation, but in the form of the characteristics, properties, state or picture of the object studied, obtained directly from the informants based on open questions when conducting interviews and focus group discussions.

\section{Sources of Data}

\section{1) Primary Data}

Obtained through: (1) observation in the area studied to get a general idea of tourism and poverty before doing research in Plaga Village and Village of BelokSidan, the village of Jimbaran and PecatuVillage, (2) through interviews, information was obtained about tourism and poverty in the respective villages and, (3) through the FGD, current information was obtainedabout the potential ofthe villagesand weaknesses for designing tourism development strategies and poverty reduction in the respective villages.

\section{2) Secondary Data}

The data were obtained from indirect sources, namely: (1) Development of Tourism with the amount of tourist arrivals to BadungRegency, Contributions of PHR, Tourists' Length of Stay, (2) Economic Performance: consisting of GDP Growth, employment absorption and investment, and (3) Poverty in Badung regency, consisting of: Number of the Poor, Percentage of Poor People, Poverty Depth Index and Poverty Severity Index. The data for 14 years (from 2000 through 2013) obtained from the Central Bureau of Statistics of Badung regency, Regional WorkUnit (SKPD) and the Central Bureau of Statistics of Bali Province. 


\section{Data Analysis Methods}

\section{Quantitative Analysis}

Quantitative analysis is used to answer the first, second, and third problems, by using analysis Partial Least Square as an alternative modeling of equations whose theoretical foundation is weak, can be used as a confirmation of the theory (Wold, 1966), and can be used forreflective and formative models(Ghozali 2011: 7 -17).

\section{Qualitative Analysis}

Qualitative analysis techniques are used to answer the four the problem formulation, namely how to develop a strategy to increase tourism's role in poverty alleviation in Badung Regency. Information or data provided are analyzed through the approach of Strength, Weakness, Opportunity and Threat (SWOT) designed through a Focus Group Discussion (FGD) with the poverty reduction strategy based on the SWOT matrix, namely: (1) SO Strategy, (2) ST Strategy, (3) WO strategy and (4) WT strategy.

\section{Results and Discussion}

\section{Geographical Conditions of Badung Regency}

Badung Regency is one of the nine regencies of Bali province, with an area of $418.52 \mathrm{~km}^{2}$ or $7.43 \%$ of the island of Bali with a wide sea area management authority covering $466.20 \mathrm{~km}^{2}$ along $81.3 \mathrm{~km}$ coastline from Mengening Beach of the District of Mengwi up to Tanjung Benoa beach in the District of South Kuta, with boundaries as follows:

1. The Northern Border: Buleleng Regency

2. East Border: Bangli Regency, Gianyar

Regency and Denpasar City

3. South Border: Indian Ocean

4. West Border: Tabanan Regency

\section{Testing Results of Partial Least Square (PLS)}

The steps used in the Partial Least Square modeling (Hidayat and Widjanarko, 2012) are as follows:

\section{Testing results of outer models or measurement models}

Analysis results of model on the effect of tourism development on economic performance and poverty reduction is presented in Figure 2.

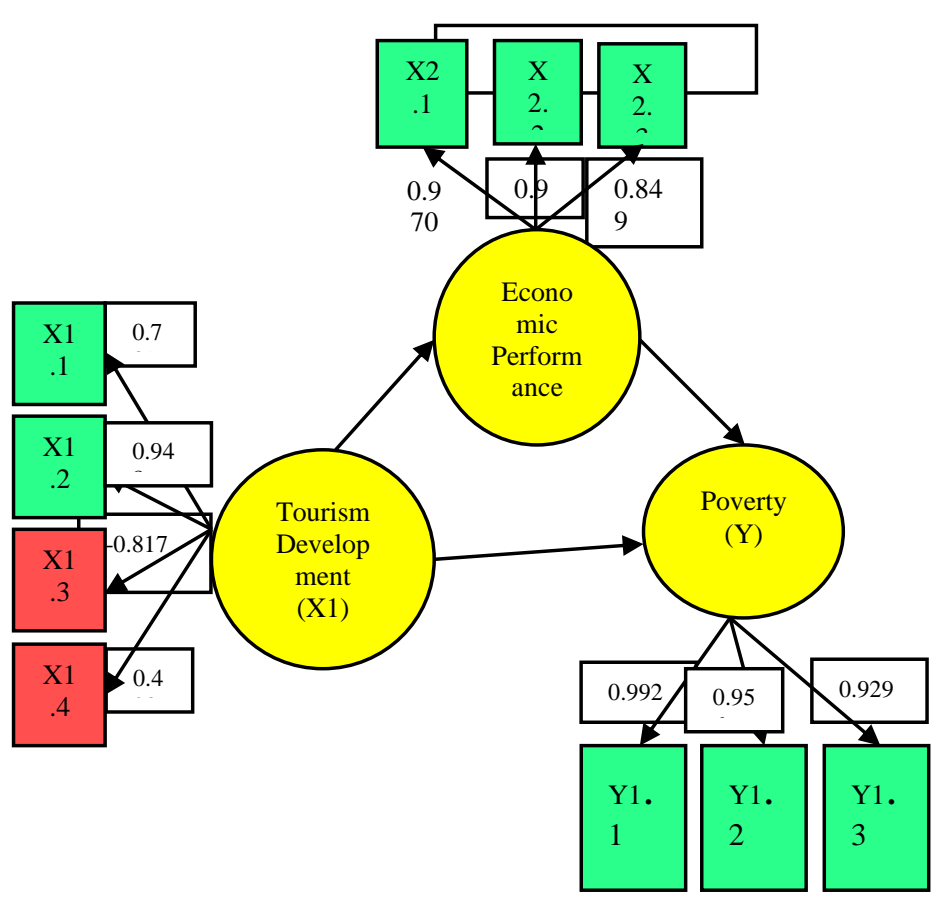

Figure 2. Analysis Results of outer research model

There are three criteria in using data analysis techniques with Smart PLS to assess outer model using PLS, that is, convergent validity, discriminant validity, as well as the average variance extracted (AVE) and composite reliability (Ghozali, 2008). Outer models are assessed by looking at convergent validity as shown in Table 5.8. This study uses the minimum limit loading factor of 0.5 . Revision of analysis results of outer model is shown in Table 5.9, complete information is presented in appendix 3. The revision of the analysis results of outer model is shown in Figure 3. 


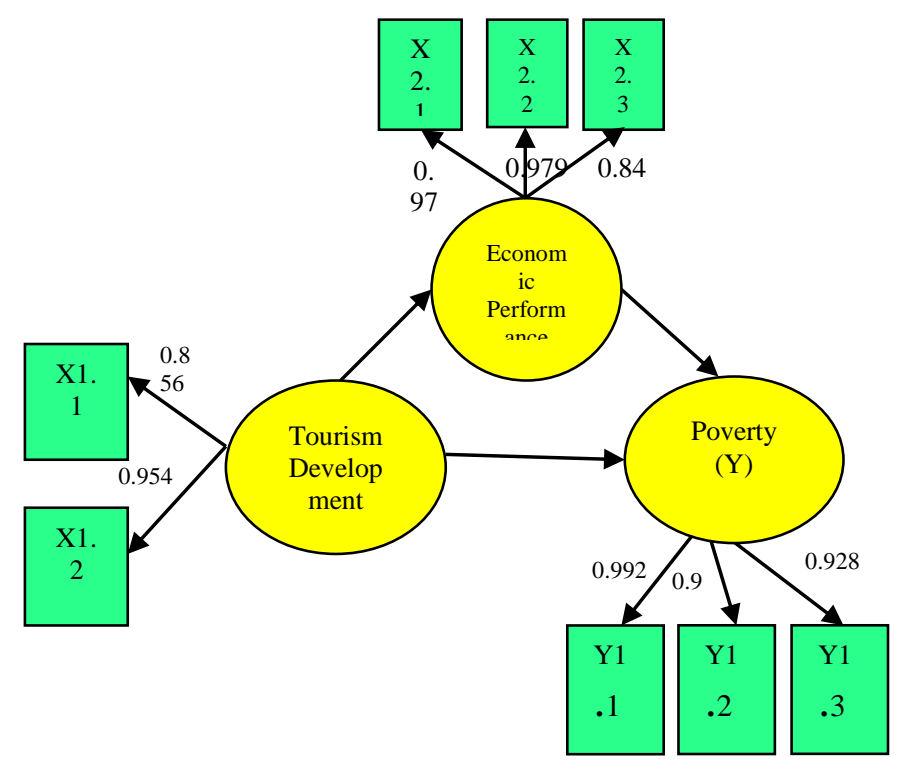

Figure 3. The revised analysis of outer models

The data processing result as shown in Table 1 shows that the value of outer models meets the convergent validity criteria, where all indicators have a loading factor above 0.50 . Therefore, it can be concluded that the construct has a good convergent validity.

\section{The test results of Discriminant validity}

Discriminant validity of the measurement model with reflective indicators (factors) was assessed by cross-loading measurement with a construct. If the construct correlation with the measurement item is larger than the size of the other constructs, then this indicates that the latent constructs predict the size of their block better than the size of the other blocks.

Table 1. Cross Loadings

\begin{tabular}{cccc}
\hline & Poverty & $\begin{array}{c}\text { Economic } \\
\text { Performance }\end{array}$ & $\begin{array}{c}\text { Tourism } \\
\text { Development }\end{array}$ \\
\hline x1.1 & -0.542 & 0.560 & 0.856 \\
x1.2 & -0.949 & 0.939 & 0.954 \\
X2.1 & -0.951 & 0.971 & 0.942 \\
X1.2 & -0.953 & 0.979 & 0.869 \\
X1.3 & -0.702 & 0.846 & 0.569 \\
y2.1 & 0.992 & -0.932 & -0.854 \\
y2.2 & 0.957 & -0.946 & -0.886 \\
y2.3 & 0.928 & -0.829 & -0.759 \\
\hline
\end{tabular}

Source: Research data

http://ojs.unud.ac.id/index.php/eot
Data in Table 1 explains that the value of cross loadings shows good discriminant validity. This can be seen from the value of the correlation indicator of construct (loading factor) which is higher than the value of the indicator correlation with other constructs.

\section{The test results of Reliability}

According Ghozali (2008: 40) that the reliability of a construct can be judged from the composite reliability that serves to measure the internal consistency whose value must be above 0.60 .

Table 2. Composite Reliability

\begin{tabular}{clc}
\hline No & Construct & $\begin{array}{c}\text { Composite } \\
\text { Reliability }\end{array}$ \\
\hline 1 & Poverty & 0.972 \\
2 & $\begin{array}{l}\text { Economic } \\
\text { Performance }\end{array}$ & 0.953 \\
3 & $\begin{array}{l}\text { Tourism } \\
\text { Development }\end{array}$ & 0.902 \\
\hline
\end{tabular}

Source: Research data

Table 2 shows that the results of the composite reliability of all the constructs are above 0.60 then construct meets the reliable criteria.

\section{Test Results of structural models (inner model)}

Inner models describe the relationship between the latent variables based on the substantive theory. In assessing the models with PLS, starting with a look at the R-squares for each dependent latent variables. The test results of inner models can see the relationship between the constructs by comparing the value of the significance and the R-square of the research model (Ghozali, 2008: 42). Inner structural diagram of the model test results are shown in Figure 4. R-square value is obtained in Table 3.

Table 3. The value of R-Squares

\begin{tabular}{clc}
\hline No & Construct & R Square \\
\hline 1 & Poverty & 0.899 \\
2 & Economic & 0.758 \\
& Performance & 0.000
\end{tabular}

Source: Appendix 4 
$\mathrm{R}$-square value of Poverty variables is 0.899 which can be interpreted that $89.9 \%$ of poverty construct variability is explained by the variable of Tourism Development and Economic Performance, while $10.1 \%$ Poverty construct is described by the variables outside the model. Likewise, the variable of economic performance has the $\mathrm{R}$ square 0.758 , which means that $75.8 \%$ variability of economic performance is caused by tourism development and $24.2 \%$ were caused by variables outside the model.

\section{Effect of Tourism Development on Economic Performance}

The first hypothesis of test results shows that the effect of tourism development on economic performance shows the value of path coefficient of 0.871 with a t-statistic value of 71.567. T-statistic value is greater than the value of $t$-table 2.201. This indicates that the development of tourism variables significantly affect the economic performance, meaning that the better performance of tourism development, economic performance will also develop. This means that the hypothesis 1 is accepted.

\section{The influence of economic performance on poverty}

The second hypothesis of test results shows a significant effect of the economic performance variables on poverty with path coefficient value of 0.762 and the value of $t-$ statistic of 15.462 . The value of t-statistic is larger than t-table value of 2.201 , indicating that there is a significant influence between the variables on poverty. Path coefficient which is negatively marked indicates that the economic performance provides a significant and negative effect on poverty. This indicates that the higher the economic performance, the lower the poverty level is. This means that hypothesis 2 is accepted.

\section{The influence of tourism development on poverty}

The path coefficients of influence tourism development on poverty at -0.207 with a t-statistic value of 4.099. T-statistic value is larger than t-table value of 2.201 which indicates that there is a significant relationship between the variables of tourism development with poverty. Path coefficient which is negatively marked shows that the development of tourism has a negative impact on poverty. It means that the better the tourism development, it has an impact on the declining poverty. This means that hypothesis 3 is accepted.

\section{Strategy of Increasing Role of Tourism and Poverty Alleviation}

Based on the results of FGD, SWOT analysis can be done with four (4) weaknesses owned by the village of Pelaga and Belok Sidan and (3) in the village of Jimbaran and Pecatu. The strategy is as follows:

\section{Village of Pelaga and BelokSidan.}

1) Location and Means of Transport.

The strategy: organizing cooperation among tourism stakeholders, from the private sectors and the government to promote sustainability.

2) Low Public Education.

The strategy: organizing competency training on tourism ranging from elementary school to high school level in each village.

3) The Poor without land ownership.

The strategy: community empowerment through micro-economic development through government bailouts or CSR support of private companies to increase community's incomes.

4) Low Understanding of Cleanliness.

The strategy is through community empowerment of tourism awareness, understanding of cleanliness and provision of waste bins in strategic places and tourist attraction.

\section{Village of Jimbaran and Pecatu}

1) Low Public Education

The strategy: training competence on tourism from elementary school to high school level in each village.

2) Poor without land ownership

The strategy: empowering the poor through micro-economic development to increase income through bailouts from the government or support CSR from private companies. 
3) Low Understanding of Cleanliness.

The strategy is through empowerment of tourism awareness, understanding of cleanliness and provision of waste bins in strategic places and tourist attraction.

\section{Limitations of the research}

1) The Use of variables is limited, i.e. variables of tourism, economic performance and poverty variables and looked at only from the economic aspect.

2) The study does not examine the effect of non-economic aspects of the poverty. Meanwhile, according to Karim, Mohammad and Serafino (2012), (Spenceley and Seif, 2003) and Ashley et al. (2001), in addition to analyzing the impact of tourism on poverty from an economic standpoint, the researchers also need to examine the impact of tourism on social and cultural life and environment.

3) This study uses secondary data from a limited resource that is from BPS (Bureau of Statistics) of Badung Government and the Province of Bali.

4) The Data time series are available only for 14 years since the establishment of Badung in 1992 split from the municipality of Denpasar

\section{Conclusions and Recommendations}

\section{Conclusions}

1. Tourism Development has a significant and positive impact on the economic performance

This means the better the development of tourism, the economic performance is increasing. It is seen from the path coefficient of 0.871 with a t-statistic value of 71.567 greater than t-table value of 2.201. This indicates that the variable development of tourism and significant positive effect on economic performance.

\section{Economic performance has a significant and negative impact on poverty.}

This means that the higher the economic performance the poverty level is declining. This can be seen from the level of path coefficient value of 0.762 with a t-statistic value of 15.462 , higher than t-table of 2,201 . Negatively marked path coefficient indicates economic performance has a significant and negative effect on poverty.

\section{Tourism development has a significant} and negative effect on poverty.

This is seen from the path coefficient of the influence of tourism development on poverty at -0.207 with a t-statistic value of 4.099 , larger than t-table value of 2.201 which indicates that there is a significant relationship between the variables of tourism development with poverty. Path coefficient indicates negative effect on the tourism development of poverty. That is: the better the development of tourism, it has an impact on decreasing poverty.

\section{Recommendation}

This study still has limitations, so to enhance further research the following recommendation sare suggested:

1) The need for ongoing research in the South Badung District in the form of a pilot project that is integrated with the involvement of local communities to develop seaweed and restore the glory of Pecatu citrus. As for the village of Jimbaran, the development of other economic activities needs financial support from the government to optimize the utilization of CSR from private companies.

2) Future studies need to be enhanced by adding non-economic variables (such as welfare) as a mediating variable between Tourism Development and Poverty.

3) To determine the influence of the role of tourism and economic performance on poverty, it needs to be supported with more primary data from wider sources.

4) Development of on-going research in North Badung, in the district of Petang, the Village of Plaga and the Village of Belok Sidan to develop modern agriculture-based community in collaboration with international agencies, governments, and private sector experience in the field of modern agriculture. 


\section{References}

Anwar, J. M. (2012) 'Poverty Alleviation Through Sustainable Tourism: A Critical Analysis Of "Pro-Poor Tourism" And Implications For Sustainability In Bangladesh'.

Armstrong, R. (2012) 'An analysis of the conditions for success of community based tourism enterprises.', ICRT Occasional Paper. International Centre for Responsible Tourism, Leeds Metropolitan University, (OP21), pp. 1-52.

Ashley, C. and Haysom, G. (2006) 'From philanthropy to a different way of doing business: Strategies and challenges in integrating pro-poor approaches into tourism business', Development Southern Africa. Taylor \& Francis, 23(2), pp. 265-280.

Ashley, C. and Roe, D. (2001) Pro-poor tourism strategies: Making tourism work for the poor: A review of experience. lied.

Ashley, C. and Roe, D. (2002) 'Making tourism work for the poor: strategies and challenges in southern Africa', Development Southern Africa. Taylor \& Francis, 19(1), pp. 61-82.

Athanasopoulou, A. (2013) 'Tourism as a driver of economic growth and development in the EU-27 and ASEAN regions', EU Center, Singapore.

Bryden, J. M. (1973) Tourism and development. CUP Archive.

Creswell, J. W. (2013) Research design: Qualitative, quantitative, and mixed methods approaches. Sage publications.

Denzin, N. K. and Lincoln, Y. S. (2008) Strategies of qualitative inquiry. Sage.
Elesh, D. (1973) 'Poverty theories and income maintenance: validity and policy relevance', Social science quarterly. JSTOR, pp. 359-373.

Goodwin, H. (1996) 'In pursuit of ecotourism', Biodiversity \& Conservation. Springer, 5(3), pp. 277291.

Guo, L. (2008) 'Pro-poor tourism in China: preliminary investigation', $P h D$ of School of Contemporary Chinese Studies. University of Nottingham, pp. $1-18$.

Harniati, A. F. (2007) 'Tipologi kemiskinan dan kerentanan berbasis agroekosistem dan implikasinya pada kebijakan pengurangan kemiskinan'. IPB (Bogor Agricultural University).

Harrison, D. (2008) 'Pro-poor tourism: A critique', Third World Quarterly. Taylor \& Francis, 29(5), pp. 851-868.

Hidayat, N. and Widjanarko, B. (2012) 'Pemoderal Structural Equation Modeling (SEM) Berbasis Varian Pada Derajat Kesehatan di Provinsi Jawa Timur 2010', in Seminar Nasional Penelitian.

Jennings, G. (2001) Tourism research. John Wiley and sons Australia, Ltd.

Juliansyah, N. (2011) 'Metodologi penelitian: skripsi, tesis, disertasi dan karya ilmiah', Kencana Prenada Media Group Jakarta.

Karim, R., Mohammad, F. and Serafino, L. (2012) 'Integrating pro-poor tourism activities in a community-based idea of development: the case of the district of Hunza-Neger, Pakistan', in Proceedings of the International Colloquium on Tourism and Leisure (ICTL), pp. 9-12.

Nehen, K. (2012) Perekonomian Indonesia. Bali: Udayana University Press. 
Papilaya, E. C. and Nastiti, D. M. (2013) 7 kiat percepatan pengurangan kemiskinan dan pemiskinan bangsa. IPB Press.

Scheyvens, R. (2002) Tourism for development: $\quad$ Empowering communities. Pearson Education.

Selinger, E. (2009) 'Ethics and poverty tours', Philosophy \& Public Policy Quarterly, 29(1/2), pp. 2-7.

Soedjatmiko, H. (2007) Saya berbelanja maka saya ada: ketika konsumsi dan desain menjadi gaya hidup konsumeris. Jalasutra.

Spenceley, A. and Seif, J. (2003) Strategies, impacts and costs of pro-poor tourism approaches in South Africa. Citeseer.

Tasci, A., Semrad, K. J. and Yilmaz, S. S. (2013) 'Community based tourism finding the equilibrium in comcec context: Setting the Pathway for the Future', Ankara: COMCEC Coordination Office.

UNWTO (2015) UNWTO/UNESCO World Conference on Tourism and Culture gathers Ministers of Tourism and Culture for the first time (Press Release) -and-culture-gathersministers-tourism-. Available at: http://media.unwto.org/pressrelease/2015-02-06/unwtounescoworld-conference-tourism.

Wahyuni, S. (2012) 'Qualitative research method: Theory and practice', Jakarta: Salemba Empat. 